\title{
Playfulness as Apologia for a Strong Story In IAN MCEWAN's SWeEt Tooth
}

\begin{abstract}
Ian McEwan's penultimate novel, Sweet Tooth (2012), is a remarkable achievement, not only in the context of the contemporary British literary scene but also within the body of its author's work. Although it is written in the form of a spy thriller, with an element of romance, the novel by far transcends the limits of this genre. It provides an intriguing exploration of McEwan's favourite themes, but also contains a notable dimension of intertextual and metafictional playfulness, which in this case is highly self-reflective as he makes direct references to his own fiction, namely to his short stories from the collection In Between the Sheets (1978). Therefore, in terms of its thematic and narrative framework, Sweet Tooth can be especially linked with two of his earlier novels, The Innocent (1990) and Atonement (2001). This article argues that McEwan's use of playful narrative strategies is not a result of his intention to write an experimental text challenging the traditional notion of the story and the plot, but rather serves as a means of his defence of a strong story as a crucial factor of a quality narrative.
\end{abstract}

Key words

Ian McEwan; Sweet Tooth; playfulness; story; intertextuality; metafiction; selfreflectiveness; spy novel

All novels are spy novels. The crucial elements are withholding, or partially leaking, information; and who's in charge - who controls the narrative.

(Ian McEwan)

Ian McEwan is one of the most widely read and critically-acclaimed contemporary British writers. His work, written over the past forty years, includes novels, novellas, short story collections, children's books, screenplays, film adaptations 
of his fiction, a play, an oratorio, a libretto and lectures. Despite this richness and diversity, the true core of his literary production can be found primarily in his novels which, though to a varying extent and in different ways, explore the themes of morality, responsibility, history, sexuality, human imagination and consciousness (Groes 2009: 2). They deal with his three favourite themes: the importance of childhood, the relationship between children and their parents especially, yet not solely, during their transition from childhood to adulthood and the far-reaching and often fatal consequences that one wrong decision made in an instant for some seemingly trivial or even trifling reason can have not only for the person who made it, but also for the people close to him or her, creating "for the reader a sense of the very ordinary and familiar as possessed of something potentially discomforting" (Bradford 2007: 18), and suggesting that what determines our life and morality is the sense of living in the presence of an imminent catastrophe (Ryan 1999: 207-208) ${ }^{1}$. In order to explore these themes from a complex set of points of view, McEwan has incorporated in his novels a variety of generic forms as well as of narrative techniques and strategies. Among the former are, for instance, the Gothic story, dystopia, spy thriller, psycho-thriller, satire, parable, romance, war narrative, country house fiction, modernist narrative and ecological fiction; the latter feature, apart from the already implied genre mixture, includes unreliable narrators, fragmentation, multiple-perspective narration, parody, playful and unexpected final twists, metafiction and intertextuality.

An essential device in McEwan's novels is one central protagonist through whose perspective the story is told, either directly in the first person, or indirectly in the third person. Exceptions to this are Amsterdam (1998) and On Chesil Beach (2007) with two major protagonists, and Atonement (2001), which combines multiple-perspective third-person and first-person narrations. What these characters share is that they face a critical situation which proves determining for their subsequent lives, one which requires an immediate decision or reaction, but also one which is so unexpected, unlikely, emotionally charged, morally unsettling or convoluted that it makes such an act very difficult if not impossible. McEwan's heroes, or anti-heroes in certain cases, are fallible individuals, sometimes more and sometimes less to be blamed for the effects of their ill decisions or inappropriate reactions, which they make or choose out of their personal, often selfish, needs or impulses rather than for morally justified, altruistic reasons. However, the fact that they have to undergo severe inner struggles before they make their mistakes and later suffer the consequences makes them not only convincing for the reader but also, at least to some extent, easier to sympathise and identify with.

McEwan's novels written since 2000 tend towards textual playfulness, by which they add new layers to their plots and thus offer further opportunities for their reading and interpretation. Sweet Tooth (2012), his to date penultimate novel, follows the same route and opens yet a new dimension to this tendency by employing autobiographical self-reflectiveness. Although, in terms of its thematic and narrative framework, Sweet Tooth can be compared with two of his earlier novels, The Innocent (1990) and Atonement, it is by no means their mere 
cross-breed but a distinctive and original book with an absorbing storyline and an ingenious metatextual overlap. Combining a Cold War spy thriller and a romance, the novel by far transcends the limits of either of these genres. Not only does it provide an intriguing exploration of the author's favourite themes, it also contains a notable degree of intertextual and metafictional playfulness, which in this case is highly self-reflective as he makes direct references to his own fiction, namely to his short stories from the collection In Between the Sheets (1978). Yet, this playfulness is not an end in itself as it is subordinate to the requirements of plot construction. The aim of this article is to demonstrate that McEwan's use of playful narrative strategies is not a result of his intention to write an experimental text challenging the traditional notion of the story, but rather serves as a means of his apologia for a strong story as a crucial factor of a quality narrative.

\section{Sweet and innocent - Sweet Tooth as a spy novel}

The fact that Sweet Tooth is written as a spy thriller ${ }^{2}$ links it with McEwan's earlier novel The Innocent. The Innocent is set in mid-1950s Berlin, during the culminating political crisis in the divided city after the outbreak of the Cold War, and revolves around a joint operation of the American CIA and the British MI6 whose aim is to build a secret tunnel between the American and Russian sectors of the city in order to tap the phone lines of the Soviet High Command. The novel's main protagonist, Leonard Marnham, is a young British Post Office engineer who is sent to Berlin to work with the Americans, his task being to set up and repair the tape recorders used in the operation and install the signals in the tunnel. The story gains its particular dynamism when Leonard meets and falls in love with an older, divorced German woman, Maria Eckdorf, with whom he has an affair and to whom he later gets engaged. Everything seems to be going smoothly for the lovers until Maria's ex-husband, Otto, a drunkard, bully and self-proclaimed war veteran, turns up in her flat, making jealous scenes and claiming that their marriage was not officially ended. During a violent fight between the two men in which Leonard is terribly beaten, Maria kills Otto. It is at this point that their fateful secret operation - getting away with the crime - begins.

There are several affinities between Sweet Tooth and The Innocent. Both their protagonists are young people who grew up in the almost idyllic seclusion of the English countryside, received some academic education without much thinking about what they would do in the future, but by force of their circumstances are sent to centres of political and social turmoil of their times and become involved in happenings controlled by the intelligence services. Therefore, their early adulthood is marked by a rapid transition from innocence to a very specific form of experience, as a result of which the amiability, tranquillity and predictability of the former appear in stark contrast with the aloofness, insidiousness and depravity of the latter. This transition is carried out through a series of parallel initiations which crucially affect the individuals on personal, social and political levels. 
Leonard is the eponymous innocent of the novel, both sexually and in his ideas: upon his coming to Berlin, he is a virgin with almost no experience with women, and he knows only very little about the mission in which he is going to take part. $\mathrm{He}$ is initiated into the structures of the intelligence service's hierarchy, some secrets of the operation and its ideological background, while in his personal life Maria shows him the "secrets" and pleasures of physical love. In combination, he gradually starts to understand the intricacy and paranoid hostility of the postWWII world trapped in a global political crisis, but, perhaps more importantly, he discovers some alarming latent aspects of his own personality of which he was not aware before.

In Sweet Tooth, Serena Frome, a "conventional girl" who "lives in unconventional times" (McEwan qtd. in Simon 2012), undergoes a similar initiation by her lover and mentor Tony Canning, a man more than thirty years her senior, who finds in her an affectionate companion and a pleasant distraction before the final days of his life, for which he "pays her back" by securing for her a position with MI5. Born about twenty years later, she is not as sexually inexperienced as Leonard, yet her innocence is also striking: she shows no interest in political, social, economic or cultural events and lives her provincial life that embraces nothing else than her university studies, dating her boyfriend and speed-reading her favourite novels. Her short but intense affair with Tony opens completely new horizons to her. By making her read newspapers and historical books, then think about them, discuss their contents and express her opinions on current issues he introduces her to a world which differs from her previous existence in all respects: one in which every single act bears strong personal responsibility, one in which the personal is inseparable from the public, one in which the weight of age and life experience is viewed as a benefit rather than burden. Serena's transition is thus from childlike indifference to mature adulthood. As in Leonard's case, her subsequent initiation into the system and ideological workings of the intelligence services is only complementary to this personal initiation, whose consequences eventually overshadow those of the actual spy activities.

Leonard and Serena are also similar with regards to why they have been chosen to work for the intelligence services, their attitude to their employers, but also their position and role in the actions they become part of. Leonard is admitted to the CIA team not because he is an exceptional expert in radiology or electrical engineering, but because they have to abide by the quotas stating the number of the British involved in the joint operation. Serena's case is even more curious, if not absurd, for, having been recruited and recommended by a discredited nuclear ex-spy, the MI5 authorities suspect her of possessing some potentially dangerous information and find it preferable to take her in so as to have her under control and at hand for a thorough screening. The fact that neither of them ever had any sincere desire or ambition to work for the intelligence services makes them both considerably ignorant of, as well as indifferent to, the larger context and implications of their respective occupations, lacking the supposed degree of ideological zeal and devoted patriotism, and being instead preoccupied with the concerns of 
their personal lives. As a result, they are treated accordingly by their superiors and more experienced colleagues: although Leonard is gradually promoted, he keeps being patronised and distrusted by the Americans; and Serena is deliberately kept from any secrets by the limited responsibilities of her position as an office girl, before she is assigned a minor "toy" task of low political priority. ${ }^{3}$

However, there are also certain substantial differences between the two stories. The first is the character of the operations in which the main protagonists become involved: although Leonard is a fictitious creation, McEwan makes him a part of Operation Gold, a real project conducted from September 1954 to April 1956, the first large and crucial secret operations of the Cold War. He even lives in the same house as a peculiar character named George Blake, who in reality was a double agent for the Soviet Union who had leaked the details of the planned operation to the KGB before it got started. On top of that, despite of Leonard's above-mentioned deficiencies as a full-fledged member of an intelligence service, McEwan sends him almost to the very battlefront of the operation as a vital provider of technical support for the team of eavesdroppers. Leonard thus finds himself in the centre of espionage warfare and has first-hand experience with the pressures and moral dilemmas resulting from the often conflicting nature of the service's demands and his personal interests.

The MI5 operation in which Serena works as an agent is completely fictitious, though it is inspired by the activities of the Information Research Department of the British Foreign Office which, primarily in the post-WWII years, was trying to use the British media and literary scene to shape public opinion by promoting anti-Soviet attitudes voiced by foremost writers and thinkers such as Bertrand Russell, Bryan Magee, Robert Conquest and George Orwell. Its most famous "literary" project, devised as a joint operation with the CIA which covertly funded it, was founding the Encounter, an Anglo-American left-of-centre yet anticommunist cultural and intellectual magazine, between 1953 and 1966, probably the closest analogy to the plot of McEwan's novel. As the former mistress of a treacherous agent, not only is Serena not allowed to participate in any substantial covert action, she is for some time even being monitored and reported on by her colleagues, and the Operation Sweet Tooth she eventually participates in is of minor significance in terms of the immediacy of its impact on the international political situation as it considered a part of the "soft" or cultural Cold War (McEwan 2012: 305), a war of ideas rather than actual espionage. Serena is thus miles away from the front lines. Moreover, her task of persuading a young writer to let himself be generously financially supported by an international foundation while writing a novel is quite undemanding. She still fails professionally when she violates the basic principle of the intelligence services and becomes emotionally involved with the subject of her mission.

Also, Serena does not have to face up to any serious trouble or crisis in the story, one which would fatally endanger either her life or the lives of other people. She also never personally encounters any truly unpleasant or cruel realities of human existence such as violence, crime and death. Compared to her, Leonard 
is forced by circumstances to cope with the consequences of an extreme situation - to cover his and Maria's tracks after their unintentional killing of Otto by getting rid of the corpse without anybody noticing. The long and morbidly detailed passage describing the two lovers disposing of the corpse functions as the climax of the novel, the turning point in the story after which nothing in the life of its participants can be as before. It also adds more suspense to the thrilling component of the plot which at this point sidelines all the others. In this respect, The Innocent echoes the tendency of McEwan's previous works, which relied heavily on various violent, perverted, bizarre, pathological or otherwise obscure moments, namely First Love, Last Rites (1975), In Between the Sheets, The Cement Garden (1978) and The Comfort of Strangers (1981).

On the other hand, Sweet Tooth lacks a few of the important attributes of a spy thriller. Strictly speaking, only the first three chapters, during which Serena is trained by Tony and then recruited by MI5, may promise the development of the novel in the direction of a suspense story. Ironically then, when she actually joins the intelligence service the narration turns into a description of her personal life, her desires and worries, mainly in her relationships with Max, Shirley and later with Tom Haley, and so the only accounts of truly thrilling actions appear in the form of stories about former agents and past secret operations she hears from Max, her superiors or the visiting lecturers. She is not exposed to any dangerous or charged situation which would call for bold, risky or radical action, and even the rare occasion when she and Shirley, disguised as cleaning ladies, are sent to clean a room where somebody had been bleeding turns out to be just a pretence to give Shirley a chance to test the sincerity of Serena's political views. She is thus left almost untouched by the turbulent affairs of the outside world, including the ongoing Cold War. Instead of giving them insight into the mind of an agent or a person trapped in a course of dramatic events, the narrative portrays the mind of a person whose primary concerns do not differ from most readers' daily reality: her longing for contentment, her insecurities and anxieties in relationships, and her fears that her happiness is too fragile to endure what the future may bring. However, the novel is not a mere romance with the background of a spy thriller either, particularly owing to its intertextual and metafictional dimensions, and so its affinity with The Innocent, employing a traditional narrative technique of an omniscient perspective (Malcolm 2002: 112), remains prevailingly on the level of its subject matter framework.

\section{Yet another way of atoning - intertextuality and metafictionality in Sweet Tooth}

The significance of the intertextual and metafictional elements in its plot links Sweet Tooth with McEwan's 2001 novel Atonement, which follows a similar strategy of presenting a love story against the backdrop of momentous affairs, yet only to gradually reveal it is a plot device for the exploration of the novel's main 
theme: the rigours of the process of creative writing, the writer's ethical dilemma concerning one's responsibilities towards the readers, characters and oneself, and the "danger of an imagination that can't quite see the boundaries of what is real and what is unreal" (McEwan qtd. in Noakes 2002: 19). Due to this similarity, the two novels have a number of other features in common. Both are written at least in large part from the perspective of a young woman, which McEwan finds liberating rather than challenging (Treisman 2012), both are dominated by a gripping story of sincere love between two young people who persist in their affection against various odds of fate because they strongly believe each other and in each other. As a result, the historical events that take place in them, although they certainly are determining for the stories and do affect the characters' lives, are in the most important moments set aside to give way to accounts of the lovers' words, acts and feelings. The role of real-life personages in the novels is also more or less instrumental and principally serves the purpose of giving the stories a greater air of plausibility and historical authenticity.

Another common feature of the two novels is the theme of childhood, the relationship between children and their parents, and how "adult identity [is] related to early life experience" (Childs 2005: 124). Although the periods of Briony's and Serena's childhoods are some thirty years apart, the 1930s and 60s respectively, in terms of the hierarchy of roles the Tallis and the Frome families are arranged according to a very similar patriarchal model, though the latter is not as extreme as the former: in the centre there is the indisputable authority of the father, a knowledgeable but preoccupied figure to be ever much emotionally involved in the process of his children's upbringing, playing thus the role of either a detached advisor or a steadfast judge whom his children simultaneously respect, fear and mock secretly, yet whose taciturn and reserved physical presence in the household seems essential for its peaceful and effective functioning. The father's authority is supported "from below" by the dutiful and caring housewife, a pragmatic woman whose life is devoted to her husband's career and the wellbeing of her children at the cost of her own suppressed aspirations. In both novels McEwan, himself a product of such an upbringing as the son of an army officer, demonstrates how illusory this peacefulness and effectiveness are, and how damaging this rigidness of the division of parental duties and the lack of emotional warmth from the father can be to children, the more sensitive and insecure ones in particular.

A related theme in these novels is that of the social role of women portrayed through the mother-daughter relationship. Both Cecilia Tallis and Serena Frome study at Cambridge University which makes them exceptional in the context of their time, even though neither of them identifies with her field much. However, that is where the resemblance ends. Cecilia applies for Cambridge in order to break free from the constraints of her home where she is permanently reminded that a university education for women is just a redundant if not even harmful distraction. Her main motivation is not academic but personal, and at Cambridge she finds herself in the company of similarly-minded liberal young men and 
women. Cecilia makes her choice against her mother's will and in defiance of her manifest disapproval, thus shows her courage and independent spirit. The choice of Serena's university and specialisation, on the other hand, is made for her by her parents and teachers. Her situation is in fact the complete reverse of Cecilia's: not only is she forced to study mathematics at Cambridge against her wish to read English literature at a provincial university, but she is manipulated into her future by her mother who feels dissatisfied with her own life and projects onto her daughter an ambition springing from "the hardy little seed of a feminist" (McEwan 2012: 3) hidden beneath her mask of undemanding loyalty and subordination to her husband's cause. And so, while the Cecilia of the 1930s is a progressive woman with independent if not feminist ideas and opinions, the Serena of the 1970s, the heyday of the second-wave feminist movement, is rather a passive creature easily suggestible by others' strong personalities, confident and worldly men above all.

However, the most significant parallel between Sweet Tooth and Atonement is the function intertextuality and metafictionality serve within their narrative and thematic frameworks, promoting "a new vision of meaning, and thus of authorship and reading: a vision resistant to ingrained notions of originality, uniqueness, singularity and autonomy" (Allen 2010: 6). Atonement is McEwan's first truly intertextual novel and numerous instances of referencing and alluding to various texts permeate the novel. Therefore, the novel's intertextuality by far exceeds the limits of a mere technical device as it is "not simply a decoration but something which consistently conveys and enhances meaning, or [...] occasionally comes into a dialogic communication with the text, i.e., transforms it or subverts it" (Grmelová 2007: 155-156). This dialogic transformation and subversion of the narrative is most effective in combination with another playful textual strategy - metafictionality. Above else, Atonement is a story about writing one particular novel and, in consequence, about the process of writing in general as it follows Briony's progress as a writer. What dominates the novel is Briony's perpetual struggle to balance the incongruity between the rules and possibilities of imaginative literature and those of reality. The final metafictional twist suggesting that the preceding text is the last version of Briony's novel which she has been unable to complete in the past fifty-nine years, thus challenges and subverts most readers' experience and presuppositions made up to then, and turns their attention to the question of the (im)possibility of fiction to ethically interfere with the realm of real life.

The principle of using intertextuality and metafictionality in Sweet Tooth is similar, only with some new effects. The novel's intertextual dimension is even more noticeable and extensive than in Atonement as its protagonist and narrator is an avid reader who has a relationship with a young writer striving to have his work published. The environment of the intelligence services is thus complemented with that of the literary scene in early 1970s Britain. What in Atonement serves its purpose in only two parts is here extended through the whole of the novel in which a large number of titles and names appear not only to enrich the 
depiction of its protagonists, but also to make this literary world more authentic and plausible. This is further supported by the fact that a vast majority of them are real, though a few which prove essential for the story are fictitious, most importantly the identity of Tom Haley and the Jane Austen Prize for Fiction which he startlingly wins in 1974, defeating many distinguished names like Anthony Burgess, Iris Murdoch, J.G. Farrell, Muriel Spark and Margaret Drabble, which is one of the most noticeable differences between Haley and his creator. The (inter) textual references thus intertwine the real and the fictitious further in a network of relations co-forming the ground on which the novel's plot can unfold.

If Briony functions as a metaphor of the development of a writer, Serena embodies that of a reader as Sweet Tooth is, among other things, "a novel about reading, [...] about what it is to be a reader" (McEwan qtd. in Chai 2012b). While in most other spheres of her life she is not very steadfast and independent but easily susceptible to other people's ideas and adaptable to their preferences, as a reader she knows very well what she likes and can be extraordinarily stubborn in standing up for it. She is an uninformed, fast-reading literary consumer, reading solely for pleasure and so all she needs is an interesting story about love, happy endings and female characters with whom she could identify, and she deems the other aspects of the books, such as the authorship, reputation, genre, theme and style of negligible importance. Serena can be taken as a parody of what may mistakenly be considered as an open-minded, unbiased postmodern reader: her taste may appear democratic and pluralistic, making no difference between popular reading, pulp fiction and canonical pieces, yet her credulous, headlong, selective and self-projective reading is in fact inconsistent with the postmodernist distrust of a narrative authority and its emphasis on the reader's active collaboration in producing meaning by carefully looking for disguised details and connections. The irony is completed when she is invited by the fellow-student editor of a proto-postmodernist weekly deliberately mixing high and low-brow scope to write a "chatty and omnivorous" (McEwan 2012: 7) column on the books she has read, but, having not understood her role, is soon dismissed when, under the influence of Solzhenitsyn, Koestler, Nabokov, Milosz and Orwell, her column becomes agitating and earnest.

Knowing her to be of an intellectually rather immature and suggestible nature, "a girl with untutored tastes, [...] an empty mind, ripe for a takeover" (McEwan 2012: 7), Serena's partners try to influence and cultivate her reading habits along with other aspects of her personal growth. Tony Canning teaches Serena to read historical non-fiction and broadsheets, including the slow and attentive way in which such texts should be approached. She makes an effort to follow her lover's instructions, but she does so only to please him, as a part of the "extended tutorials" (McEwan 2012: 26), as she calls their weekend stays at Tony's cottage, some unavoidable supplement to their cooking, dining, talking and love-making, and after the affair is over she soon resumes speed-reading novels. And when, perhaps still under Tony's influence, she tries to read reputable female writers like Lessing, Drabble and Murdoch, she takes pride in having acquired a degree of 
taste but finds them too sophisticated and socially distant, craving instead "a form of naïve realism" (McEwan 2012: 65) consisting of a degree of accuracy, resemblance to her own life and compulsory happy endings. Therefore, she disregards the postmodernist writers whose narrative strategies were undermining her belief, or rather fond hope, that "life was a fiction anyway" (McEwan 2012: 66). And so, ironically yet symptomatically, the only token she has after Tony's death is a gift-shop bookmark he bought her to prevent her from damaging books by lying them open and face down, a kitsch item whose character matches her reading preferences.

The irony shifts in a yet more piquant manner when she falls for Tom Haley, a beginning writer who follows the literary tradition that contests conventional realism by various forms of experiments and games with the reader, cherishing the modernists and favouring postmodernist contemporaries such as John Barth, Thomas Pynchon, John Fowles, B.S. Johnson, J.G. Ballard and John Calder. His fiction is notable for a mixture of detached cynicism, ironic non-realistic elements, perverted and macabre motifs, surprising or shocking twists and playing with the reader's expectations and assumptions. However, Serena still applies her own criteria to his stories and keeps ending up irritated by their inconclusive endings, absence of psychological insight, distracting details, merciless cruelty, occasional deliberate implausibility and pessimism, drawing a conclusion that they must reflect their author's disturbed mind, and insisting that "[w]riters owed their readers a duty of care, of mercy" (McEwan 2012: 105), and that the "invented had to be as solid and as self-consistent as the actual" (McEwan 2012: 193). Like Tony, Tom attempts to refine Serena's reading by introducing her to poetry and giving her more "appropriate" books as presents, and, as with Tony, she submits, gradually even gaining some insight into the art of creative writing when she is correcting Tom's story based on a mathematical probability ploy, realising the significance of the imaginative "pure invention, the spark, the hidden element" (McEwan 2012: 214) that transforms the individual elements of the narrative into a cohesive, convincing yet engaging whole.

As in Atonement, the intertextual aspect in Sweet Tooth is closely interconnected with the metafictional. This "forensically plotted novel" (Daniel 2012) deals with the theme of writing and creative literature from several perspectives: through Operation Sweet Tooth it explores literature's potential function of shaping public opinion when used, or abused, for political and ideological purposes; through Tom's mention of Operation Mincemeat it exemplifies how literature can inspire the deception exercise of espionage; and, through the Jane Austen Prize it shows the stresses and pressures of professional writing and the ambiguous role such awards play in writers' careers. The novel's pivotal metafictional comments are those on Tom's writing, and writing as such. It is also ironic that an absolute majority of them are voiced by Serena while the author is mostly silent about his own creation, save for a few terse remarks. Yet this is completely reversed in the last chapter, which also serves as the narrative's crucial final twist, which is comprised entirely of Tom's letter to Serena in which he informs her that it 
was their own lives which were the subject of his new novel, and also gives her a thorough description of how he was writing it, including that of the necessary research and investigation into her past. In this short but elaborate piece of writing he manages to make fun of her on two different levels, while, at the same time, the piece remains kind and tender in its tone. The first level is that of the story, a spy being spied on by the object of her spying, which lists the people he had to approach to obtain the information about her he needed if he wanted to become "her" as the narrator, making a point that what really matters is not whose story is told, but who is in charge of the narrative. The other level aims at Serena as a reader: although he has been teasing her throughout the letter, the same way he tends to tease his readers in his stories, he finally assures her that it will close with a sentimental happy ending just as she likes in stories: "What I'm working my way towards is a declaration of love and a marriage proposal. Didn't you once confide to me your old-fashioned view that this was how a novel should end, with a 'Marry me'?" (McEwan 2012: 319). Therefore, by accepting Tom's proposal she not only gains the man she loves, but also allows her wish to make her life a fiction come true.

The final metafictional twists in Atonement and Sweet Tooth are similar in principle as they reveal that the text the reader has been reading up to that point turns out to be a novel written by one of its protagonists, which was impossible to publish for decades for legal reasons. However, there are also a few important differences between them. In Sweet Tooth the alleged author of the novel is not its narrator, but in fact the subject of someone else's narrative. Moreover, the two books differ in the purpose and motivation behind their characters' writing of their novels: while in Atonement it is the writer's need to come to terms with her past and atone for her act that ruined two young people's lives, in Sweet Tooth it is a sudden opportunity to make a good story from one of the ironies of fate and, in one blow, inventively make use of it to save a relationship which may otherwise go wrong. And so it also "atones", yet in a different sense of the word: to reconcile. Therefore, Sweet Tooth, perhaps ironically again, really ends well with the young lovers getting married and living happily ever after, which is also the elemental condition for the fictitious novel to be released. These make Sweet Tooth less uncompromising, more light-hearted and even more playful than its predecessor.

\section{Not McEwan, but not completely not McEwan - autobiographical reflec- tion in Sweet Tooth}

There is one more meta-textual narrative strategy in Sweet Tooth which McEwan did not employ much in his previous fictions ${ }^{4}$, and which contributes to the narrative's playfulness - autobiographic referencing and reflectiveness. Sweet Tooth is McEwan's most autobiographical novel to date, a kind of a "muted and distorted autobiography" (McEwan qtd. in Cooke 2012), which is achieved through the parallels between himself and the character of Tom Haley who, as McEwan puts 
it, "is not [him], but not completely not [him]" (Jaggi 2012). The novel is set in the early 1970s, the formative years for its author, and he projects into Tom aspects of his own young self: like McEwan, Tom grew up in Suffolk, studied at the University of Sussex, experienced his first great love at the Brighton seaside, and graduated from the University of East Anglia in Norwich. After moving to London, Tom frequents the Pillars of Hercules pub and "other literary haunts in London" (Jaggi 2012), where McEwan made friends with other talented members of his generation, such as Martin Amis, Julian Barnes, Craig Raine and Christopher Hitchens, forming "a sort of disparate London School of Literature" (Greig 2012). Serena Frome, the main heroine and Tom's girlfriend, is loosely based on Polly Bide, McEwan's girlfriend from his days at the University of Sussex (Greig 2012).

A few more autobiographical aspects can be traced in the text, for example, the fact that although at that time McEwan was well aware that the country was falling apart with the labour strikes, political instability and IRA terrorist acts, he was actually very happy, experiencing his first professional successes and being in love (cf. Jaggi 2012, Wyndham 2012, Chai 2012a), which in effect made him rather oblivious of the external state of affairs, like his young lovers in Sweet Tooth. Even Tom's public reading with Martin Amis at Cambridge is based on McEwan's own experience, though in reality it took place at the $92^{\text {nd }}$ Street $Y$ in New York some five years later and, thanks to Hitchens's quick-witted hosting intervention during which he calmed down an audience aroused by Amis's hilarious performance, it did not turn out a complete failure for McEwan. Naturally, there are also several differences between them: after graduation Tom undertakes a doctorate in literature and teaches at university before settling in London in 1973. McEwan, on the other hand, "travelled through the Middle East and spent 18 months in a tiny flat in Norwich before moving to London in 1974" (Wyndham 2012). Unlike McEwan, Tom does not befriend his more famous contemporaries and Amis even treats him with patronising dismissal. And, unlike his fictional alter ego, McEwan was not offered a stipend by a beautiful blonde MI5 agent.

However, the crucial similarities between Ian McEwan and Tom Haley are those concerning their writing and literary careers. Tom's style and thematic preoccupations, the "troubling aesthetics of provocation" (Baxter 2009: 14) presenting "a gross exaggeration of the worst aspects of male sexuality" (Bradford 2007: 142 ) that not only demands "that we, the readers, immerse ourselves imaginatively in every disturbing texture of each narrative", but also insists, "in a sense, that we stay there" (Baxter 2009: 13), corresponds with that of McEwan's early pieces. Also, the beginning of his career is framed by the same people, namely Ian Hamilton, a critic, reviewer, poet, editor and publisher who started The New Review, an influential literary magazine published between 1974 and 1979, and Tom Maschler, the head of the Jonathan Cape publishing house. Both men, and also Martin Amis, are given cameo roles in the story when the former accepts Tom's stories in The New Review, and the latter publishes his first novel entitled From the Somerset Levels. Several of McEwan's own stories appeared in The New Review before they were published in the collections First Love, Last Rites 
and In Between the Sheets, and Maschler was the person who discovered him and offered to publish his works. Furthermore, some of Tom's stories strikingly resemble McEwan's, for instance, that of a man who falls in love with a department store mannequin and the one about a female novelist struggling to write her second novel and narrated by a talking ape echo McEwan's "Dead As They Come" and "Reflections of a Kept Ape" from In Between the Sheets. Most importantly, Tom's novel about a father and daughter wandering through a post-apocalyptic London is in fact McEwan's own, unfinished and abandoned novel, a part of which was published in Encounter under the title "Without Blood" in August 1975, and the whole of which appeared three years later as "Two Fragments: March 199-" in In Between the Sheets. Although McEwan does not spare his alter ego flaws, failures and embarrassing moments, such as his proud egotism at being published, his disappointment at having a story rejected, and the humiliating experience of a public reading (having to read after Amis), with Tom's novel he dares to give himself a treat by letting it be awarded the Jane Austen Prize for Fiction, beating a whole parade of celebrated writers, and making Haley the first first-time novelist to have ever won the prize. Moreover, McEwan does not miss the chance to emphasise that From the Somerset Levels is also the shortest awarded book in the history of the prize, despite the critics' objections that there is "something unmanly or dishonest about a short novel" (McEwan 2012: 268), which are almost precisely the same words he has used in his public argumentation in defence of the novella as a more superior form than the novel ${ }^{7}$. Ironically enough, his most famous and appreciated novel, Atonement, also happens to be his longest, and Sweet Tooth, which reproduces these words, the second longest.

\section{You can have it both ways - conclusion}

Despite the textual strategies discussed above, McEwan is a writer who has always acknowledged the importance of a strong, intriguing story for a good book. At the same time, he points out that storytelling is, in a way, "corrupt and corrupting" (Wood 2013: 187). Therefore, he employs intertextual, metafictional and autobiographic referencing devices not in order to undermine and disrupt the narrative, but to enrich it and make it more layered, complex and erratic and thus more meaningful for attentive, inquiring and informed readers. What he argues for, on the one hand, is an absorbing story in the $19^{\text {th }}$ century novelistic tradition which, on the other hand, "reflects upon itself", and this "self-reflection is crucial to the story itself" (McEwan qtd. in Chai 2012b). In Atonement, Connolly reproaches Briony's "Two Figures by a Fountain" for lacking "the backbone of a story" (McEwan 2002: 314), and, similarly, the postmodernist experimenter Tom in his letter to Serena repeatedly stresses that it was the sudden opportunity and the gift of a story that captured him and kept him under its spell while he was writing his second novel (McEwan 2012: 305, 315). The result of this combination of a carefully built plotline and postmodernist metacommentary in Sweet 
Tooth is a self-reflective roman à clef with the façade of a spy thriller and a love story whose happy ending is the actual "key" to the text's puzzle. As McEwan sympathises with both Serena's and Tom's view of what a good novel should be like, he sees Sweet Tooth as "an attempt to bring these lovers together", but also as "the novel that they both could love" (McEwan qtd. in Chai 2012b). The novel may not be as original and acclaimed as Atonement, especially due to its use of a technically similar final twist, but it certainly does present a new side of McEwan as a writer, moreover a writer still at the height of his powers. Its main strength is in inviting a variety of readings, and the author's apologia for the story by means of narrative playfulness ranks among the most remarkable and exhilarating of them. McEwan believes that the essence of a novel's charm is curiosity in its many forms since if a novel does not arouse curiosity it is "dead in your hands" (McEwan qtd. in Stock 2013). Seen from this perspective, Sweet Tooth is indeed a book in a vital condition.

\section{Notes}

1 This is what makes James Wood label McEwan "the great contemporary stager of traumatic contingency as it strikes ordinary lives" (2013: 180).

$2 \quad$ While doing research for the novel, McEwan met David Cornwell, better known by his penname John le Carré, for a long lunch to consult with him the details of the functioning of MI5 (Wyndham 2012, Stock 2013), and even unsuccessfully tried, together with his son, to apply online for a job at MI5 (Daniel 2012).

3 In his portrayal of the role of women in MI5, McEwan was inspired by Stella Remington, "the first female Director General of MI5 and a controversial chair of the Booker judges in 2011", whose memoirs he read and who is referred to in the story as Millie Trimingham (Stock 2013).

4 Save for one exception in Saturday (2005) where he implicitly refers to the enigmatic timehopping scene at the window of a countryside pub from his novel The Child in Time (1987).

5 Cf. "Ian McEwan claims the novella is better than the novel" and "McEwan is lucky to be allowed to publish novellas" (The Telegraph, 15 October, 2012), or "The Reading Life: In praise of the novella" (Los Angeles Times, 30 October, 2012).

\section{References}

Allen, Graham (2010 [2000]) Intertextuality. London and New York: Routledge.

Baxter, Jeannette (2009) “Surrealist Encounters in Ian McEwan's Early Work”. In: Groes, Sebastian (ed.) Ian McEwan: Contemporary Critical Perspectives. London: Continuum, 13-25.

Bradford, Richard (2007) The Novel Now: Contemporary British Fiction. Oxford: Blackwell Publishing.

Chai, Barbara (2012a) "Ian McEwan Revisits the Past with Sweet Tooth (Part 1)". The Wall Street Journal. 29 October 2012. 2 February 2015. http://blogs.wsj.com/speakeasy/2012/10/29/ianmcewan-revisits-the-past-with-sweet-tooth-part-1/>.

Chai, Barbara (2012b) "Ian McEwan on his Ambitions for Sweet Tooth (Part 2)". The Wall Street Journal. 30 October 2012. 2 February 2015. <http://blogs.wsj.com/speakeasy/2012/10/30/ianmcewan-on-his-ambitions-for-sweet-tooth-part-2/>.

Childs, Peter (2005) “'Fascinating violation': Ian McEwan's children”. In: Bentley, Nick (ed.) British Fiction of the 1990s. London: Routledge, 123-134. 
Cooke, Rachel (2012) "Ian McEwan: 'I had the time of my life"”. The Guardian. 19 August 2012. 2 February 2015. <http://www.theguardian.com/books/2012/aug/19/ian-mcewan-sweet-toothinterview>.

Daniel, Caroline (2012) "Lunch with the FT: Ian McEwan". The Financial Times. 24 August 2012. 2 February 2015. <http://www.ft.com/cms/s/2/a54cd796-eba3-11e1-9356-00144feab49a.html>.

Greig, Geordie (2012) "Sex, spies, the Seventies and me: Writer Ian McEwan in his most revealing interview yet”. MailOnline. 20 August 2012. 2 February 2015. <http://www.dailymail.co.uk/ femail/article-2190237/Sweet-Tooth-Author-Ian-McEwan-talks-sex-spies-1970s-new-book. html>.

Grmelová, Anna (2007) ““About suffering they were never wrong, the old masters': An intertextual reading of Ian McEwan's Atonement”. In: Procházka, Martin (ed.) Litteraria Pragensia 17 (34). Praha: Univerzita Karlova, 153-157.

Groes, Sebastian (2009) "A Cartography of the Contemporary: Mapping Newness in the Work of Ian McEwan”. In: Groes, Sebastian (ed.) Ian McEwan: Contemporary Critical Perspectives. London: Continuum, 1-12.

Jaggi, Maya (2012) "All Novels Are Spy Novels: Ian McEwan Talks Sweet Tooth and His Life". The Daily Beast. 15 November 2012. 2 February 2015. <http://www.thedailybeast.com/articles/2012/11/15/all-novels-are-spy-novels-ian-mcewan-talks-sweet-tooth-and-his-life.html>.

Malcolm, David (2002) Understanding Ian McEwan. Columbia: University of South Carolina Press.

McEwan, Ian (2002 [2001]) Atonement. London: Vintage.

McEwan, Ian (2012) Sweet Tooth. London: Jonathan Cape.

Noakes, Jonathan (2002) "Interview with Ian McEwan". In: Reynolds, Margaret and Jonathan Noakes (eds.) Ian McEwan: the essential guide. London: Vintage, 10-23.

Ryan, Kiernan (1999) "Sex, Violence and Complicity: Martin Amis and Ian McEwan”. In: Mengham, Rod (ed.) An Introduction to Contemporary Fiction. Cambridge: Polity Press, 203-218.

Simon, Scott (2012) “Ian McEwan's Sweet Tooth Pits Spy Vs. Scribe”. NPR. 10 November 2012. 2 February 2015. <http://www.npr.org/2012/11/10/164403949/ian-mcewans-sweet-tooth-pits-spyvs-scribe $>$.

Stock, John (2013) “Ian McEwan: John le Carré deserves Booker". The Telegraph. 3 May 2013. 2 February 2015. <http://www.telegraph.co.uk/culture/books/10033653/Ian-McEwan-John-leCarre-deserves-Booker.html>.

Treisman, Deborah (2012) “This Week in Fiction: Ian McEwan”. The New Yorker. 20 April 2012. 2 February 2015. http://www.newyorker.com/books/page-turner/this-week-in-fiction-ian-mcewan>.

Wood, James (2013 [2012]) The Fun Stuff and Other Essays. London: Jonathan Cape.

Wyndham, Susan (2012) "Interview: Ian McEwan". The Sydney Morning Herald. 8 September 2012. 2 February 2015. <http://www.smh.com.au/entertainment/books/interview-ian-mcewan20120906-25faz.html>.

Petr Chalupský is the Head of the Department of English Language and Literature at the Faculty of Education of Charles University in Prague, where he teaches English Literature, Literary Studies and Literary Theory. Specialising in contemporary British fiction, he has published articles in international journals such as the World Journal of English Language, the European Journal of English Studies and the English Language and Literature Studies. He has contributed to Beyond 2000: The Recent Novel in English (Wałbrzych, 2011) and Literary Childhoods: Growing Up in British and American Literature (Pardubice, 2008). In 2009 he published the monograph The Postmodern City of Dreadful Night: The Image of the City in the Works of Martin Amis and Ian McEwan.

Address: Dr. Petr Chalupský, Department of English Language and Literature, Faculty of Education, Charles University, Celetná 13, 116 39, Praha 1, Czech Republic. [petr.chalupsky@pedf.cuni.cz] 
